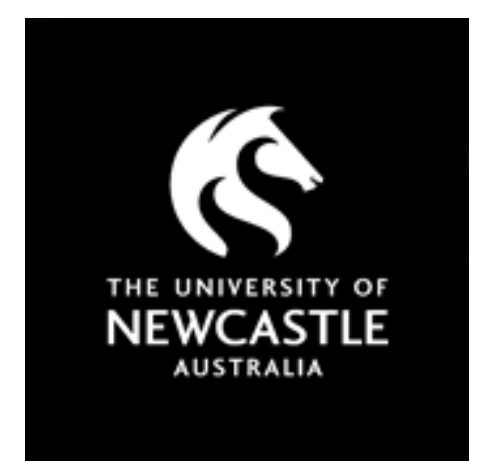

\title{
NOVA
}

University of Newcastle Research Online

nova.newcastle.edu.au

Jensen, M. E.; Collins, C. E.; Gibson, P. G.; Wood, L. G. "The obesity phenotype in children with asthma", Paediatric Respiratory Reviews Vol. 12, Issue 3, p. 152-159 (2011)

Available from: http://dx.doi.org/10.1016/j.prrv.2011.01.009

Accessed from: http://hdl.handle.net/1959.13/936859 


\section{The Obesity Phenotype in Children with Asthma}

Jensen ME, BNutrDiet ${ }^{1,2}$

Collins $\mathrm{CE}, \mathrm{PhD}^{3}$

Gibson PG, FRACP, MBBS ${ }^{1,2}$

Wood LG, $\mathrm{PhD}^{1,2, *}$

\section{Accepted 6.5.10.}

DF

\footnotetext{
${ }^{1}$ Department of Respiratory and Sleep Medicine, Hunter Medical Research Institute, John Hunter Hospital, Newcastle, 2310, NSW, Australia

${ }^{2}$ Centre for Asthma and Respiratory Diseases, University of Newcastle, 2308, NSW, Australia

${ }^{3}$ School of Health Sciences, Faculty of Health, University of Newcastle, Newcastle, NSW, 2308, Australia

* Corresponding author. Department Respiratory and Sleep Medicine, Level 3, Hunter Medical Research Institute, John Hunter Hospital, Locked Bag 1, Hunter Region Mail Centre, NSW, 2310, Australia. Tel.: +61 2 49855677; fax: +61 24985 5850. E-mail address: lisa.wood@newcastle.edu.au (L.G. Wood).
} 


\begin{abstract}
Asthma and obesity have been increasing in prevalence internationally among children. Evidence points to an association between these chronic morbidities, suggesting the development of an 'obese asthma' phenotype in childhood. This review summarises the evidence that the proinflammatory environment created by excess adiposity may provide a mechanism leading to obese asthma in children and adolescents. Weight loss studies conducted in children without asthma have demonstrated a reduction in systemic inflammation. However, the impact of weight loss in the obese paediatric population with asthma has not been investigated. The paucity of information highlights the need for high quality randomised controlled trials of weight loss in this population that include assessment of systemic and airway inflammation, and clinical asthma outcomes. This will lead to refinements in management approaches for these patients.
\end{abstract}




\section{The Link between Obesity \& Asthma}

Asthma has become increasingly prevalent worldwide over the past two decades in children and adults ${ }^{1}$. While this trend may have plateaued or slightly reversed in children, asthma remains the most common chronic condition impacting Australian children and adolescents, affecting $10 \%$ of children $\leq 14 \mathrm{yrs}^{2}$. Childhood obesity rates have also been climbing globally over the past 20yrs with an estimated 22million children $<5$ y overweight in $2007^{3}$ while approximately $17 \%$ and $6 \%$ of Australian youths aged 2-16yrs are overweight and obese respectively ${ }^{4}$.

Asthma and obesity have serious health consequences and significant financial costs. The burden of obesity on pulmonary function in children is highlighted by the increased frequency of bronchial hyper-responsiveness, increased number of prescribed medications and inhaled corticosteroid (ICS) use, and reduced peak expiratory flow rate in overweight / obese asthmatic children compared to nonoverweight asthmatic children ${ }^{5,6}$. Excess body weight is also associated with an increase in the number of school days missed by asthmatic children and significantly reduced quality of life ${ }^{6}$.

Longitudinal studies have demonstrated a link between asthma and obesity in children and adolescents. Children who were overweight / obese at study enrolment ${ }^{7,8}$ or who gained excess weight during the study ${ }^{7}, 9$, were found to be at increased risk of bronchial hyper-responsiveness, asthma symptoms and diagnosis. Gender differences in asthma risk have been noted with some studies only finding an increased risk for females ${ }^{7,9}$. These longitudinal studies demonstrate that excess adiposity preceded the development of asthma and respiratory symptoms in children and adolescents. However, recently published data from the Longitudinal Study of Australian Children has indicated asthma may also lead to the development of obesity. Children aged 45yrs suffering from wheeze or asthma, regardless of their baseline weight status, were more likely to become overweight / obese at age 6-7yrs compared to non-asthmatic children ${ }^{10}$.

\section{The Obese Phenotype in Asthma}


Epidemiological data obtained from adult populations suggests that 'obese asthma' exists as a distinct clinical phenotype, involving noneosinophilic inflammation. The association between asthma and obesity appears to be more prominent in nonatopic disease $^{11}$ with no relationship shown between obesity and atopy or eosinophil counts $^{12}$, nor total or specific IgE levels ${ }^{13}$. This supports the hypothesis that obesity promotes the development of a Th1-mediated nonatopic form of asthma. A recent cluster analysis has identified distinct asthma phenotypes in adults, that exhibit different clinical responses to treatment ${ }^{14}$. A key cluster identified was obese, noneosinophilic asthma.

The pathogenesis of 'obese asthma' in children is unknown. However, characteristic of noneosinophilic asthma ${ }^{15}$, obese asthmatic adults are resistant to inhaled steroid treatment ${ }^{16}$ and thus require alternative treatment approaches. Evidence suggests that obese asthmatic children may also be steroid resistant, as they more frequently use $\mathrm{ICS}^{6}$ and use an increased number of prescribed medications in comparison to nonobese asthmatic children ${ }^{5}$. The relationship between obesity, inflammation and asthma in the paediatric population is considered in this review.

\section{Obesity \& Systemic Inflammation in Children}

Adipose tissue communicates with other organs through endocrine capabilities ${ }^{17}$, releasing important mediators produced by tissue-resident macrophages and adipocytes, including tumour necrosis factor- $\alpha$ (TNF- $\alpha$ ), interleukins, leptin and adiponectin ${ }^{18}$. Obesity creates a proinflammatory environment via an increase in adipocyte volume and number and production of inflammatory mediators ${ }^{17,18}$. The presence of excess adiposity therefore provides a consistent stimulus for chronic, low grade systemic inflammation.

\section{Leptin}

Leptin typically stimulates a Th1 cytokine response that leads to the production of additional pro-inflammatory cytokines ${ }^{18}$. The amount of leptin secreted by adipose tissue is in direct proportion to the level of adiposity ${ }^{17}$. Under normal conditions, leptin acts through the hypothalamus as an appetite suppressant and metabolic stimulant ${ }^{19}$. Interestingly, cross-sectional studies comparing obese children with age- 
and sex- matched non-obese children have consistently found significantly higher circulating leptin levels in obese children $^{20-22}$ (See Table 1), suggesting leptin resistance occurs.

\section{Adiponectin}

Adiponectin has anti-inflammatory effects, inhibiting nuclear factor-kappaB (NF-kB), interleukin-6 (IL-6) and TNF- $\alpha$ production while up-regulating IL-10 and IL-1 receptor antagonist production ${ }^{18}$. Cross-sectional studies have found that adiponectin levels are significantly lower in obese children compared to non-obese children ${ }^{22-24}$ and correlate negatively with adiposity indices ${ }^{22-25}$ (See Table 1). Lower adiponectin levels have also been associated with increased CRP levels in obese children and adolescents compared to non-obese equivalents ${ }^{26}$.

\section{C-Reactive Protein (CRP)}

CRP activates NF-kB signalling, complement \& tissue factor, and the production of cytokines and chemokines which subsequently produce more CRP, creating a positive feedback loop ${ }^{27}$. Studies have identified a positive relationship between BMI and CRP with significantly higher CRP levels consistently documented in obese children and adolescents compared to non-obese controls ${ }^{22,24,28-30}$ (See Table 1). Furthermore, CRP levels have been documented to increase with increasing adiposity and insulin resistance measures, with a regression model identifying waist circumference as an independent predictor of CRP levels ${ }^{26}$.

\section{Interleukin-6 (IL-6)}

IL-6 contributes to inflammation by raising CRP levels and suppressing adiponectin production $^{17}$. Multiple cross-sectional studies have identified significantly elevated levels of IL-6 in obese compared to non-obese children and adolescents ${ }^{20,28,31}$, while only one study failed to identify a significant difference in IL-6 levels between these two groups ${ }^{22}$ (See Table 1). Interestingly, one paediatric study demonstrated that IL-6 levels are positively associated with adipocyte diameter but not with percentage fat or $\mathrm{BMI}^{32}$.

\section{Tumour Necrosis Factor-alpha (TNF- $\alpha)$}

TNF- $\alpha$ contributes to a proinflammatory environment by stimulating NF-kB signalling and increasing production of acute phase proteins and cytokines ${ }^{19,} 27$. Levels of TNF- $\alpha$ have been found to be significantly higher in obese children and 
adolescents compared to non-obese subjects $^{20,24,30}$ (See Table 1). Chronically elevated TNF- $\alpha$ levels impair the anorexigenic effects of leptin and insulin ${ }^{33}$, suggesting increased TNF- $\alpha$ levels may contribute to the apparent leptin resistance in the obese population. A positive correlation between adipocyte diameter and TNF- $\alpha$ levels is documented, although BMI and fat mass have failed to correlate with TNF- $\alpha$ levels ${ }^{32}$.

\section{Obesity, Inflammation \& Asthma in Children}

Asthma may present via the acquired immune system, with the key defining feature being the dominating presence of airway eosinophils ${ }^{34}$ or via the innate immune system, characterised by increased levels of airway neutrophils ${ }^{35}$. Eosinophilic and neutrophilic asthma are activated by different stimuli and function via different pathways. Eosinophilic asthma is activated by allergens and the inflammatory pathway is primarily driven by $\mathrm{IL}-5^{35}$. On the other hand, neutrophilic asthma is activated by viruses, bacteria, pollutants, and dietary components and involves an IL8 driven inflammatory pathway ${ }^{35,36}$. Increased airway inflammation in children is associated with a poorer asthma prognosis as indicated by increased severity, nocturnal symptoms, wheezing and airflow obstruction ${ }^{34}$. There is also evidence of systemic inflammation in children with asthma which may be exacerbated by the systemic inflammatory process caused by obesity ${ }^{37-39}$.

The chronic inflammatory process created by excess adiposity has been implicated in the pathophysiology of numerous conditions ${ }^{18}$ and it may also be an underlying factor in asthma pathogenesis, with the hypothesis that the increase in obesity-associated systemic inflammatory mediators exacerbates pulmonary inflammation, a direct component of asthma pathophysiology (See Figure 1).

\section{Leptin}

Leptin may contribute to asthma pathogenesis via vascular endothelial growth factor (VEGF)-induced airway remodelling and angiogenesis, as VEGF release from human airway smooth muscle (ASM) cells is enhanced following leptin stimulation ${ }^{40}$. In allergic mouse models, exogenous leptin enhanced airway hyperresponsiveness (AHR) after ovalbumin challenge ${ }^{41}$ and augmented the airway inflammatory response 
to ozone, with increases in BAL levels of IL-6, eotaxin, MIP-2, KC, sTNFR1 and sTNFR2 ${ }^{42}$. In a murine pneumococcal pneumonia model, exogenous leptin increased BAL neutrophil count, IL-6 and LTB $_{4}$ levels and macrophage phagocytosis ${ }^{43}$.

Cross-sectional studies have found significantly higher leptin levels in healthy weight asthmatic children versus healthy controls ${ }^{38,39}$, with increased leptin levels identified as a predictive factor in asthma onset ${ }^{38}$ (See Table 1). Multiple regression analysis indicated that both asthma and BMI predicted leptin levels in children ${ }^{38}$. Another study evaluated the association between leptin, asthma and BMI across 3 age groups and found no association between leptin and asthma in aged 3-18yrs and 9-24yrs but found higher leptin levels in obese asthmatic adults compared to non-obese asthmatic adults $^{44}$. In a 12yr follow-up study in children, leptin levels were significantly higher in overweight children with asthma compared to overweight non-asthmatic children ${ }^{45}$. Interestingly, there was no difference in leptin levels between the non-overweight children with and without asthma. The potential for leptin to contribute to obese asthma exists and further investigation is warranted.

\section{Adiponectin}

Adiponectin inhibition of vascular smooth muscle proliferation has been demonstrated $^{19}$. If this function is exerted in the airways, ASM mass may increase in the presence of reduced adiponectin levels, contributing to asthma. However, in vitro studies to date have not been able to establish this link ${ }^{40}$. A cohort study found no association between adiponectin and asthma during childhood, adolescence or adulthood $^{44}$. In addition, cross-sectional analysis of non-atopic asthma, atopic asthma, and controls found no difference in adiponectin levels between the groups of children $^{25}$. However, adiponectin correlated positively with FEF25-75\% ${ }^{25}$. Levels of adiponectin are yet to be compared in the obese and non-obese paediatric population with and without asthma.

\section{C-Reactive Protein (CRP)}

CRP was shown to be elevated in asthmatic children during periods of exacerbation, with CRP levels negatively correlating with $\mathrm{FEV}_{1}{ }^{46}$. Although there was no association between BMI and CRP levels, all subjects were non-obese so the data set does not elucidate the CRP levels in the obese ${ }^{46}$. Interestingly, the largest CRP reduction following resolution of exacerbation was measured in those in the lowest 
BMI percentile suggesting the leanest children have low levels of background CRP. A recent study in obese and non-obese children, with and without asthma, failed to find a significant difference in CRP levels between the groups ${ }^{37}$ (See Table 1). However, this study was limited by its sample size. Further investigation is needed.

\section{Interleukin-6 (IL-6)}

IL-6 is involved in the acute-phase and late-phase asthma response $\mathrm{e}^{7,27}$ and correlates with asthma disease activity ${ }^{47}$. Cell studies obtained from children with and without asthma have found a significantly increased release of IL-6 from the epithelial cells of children with asthma ${ }^{48}$. Increased levels associated with obesity therefore have the potential to contribute to increased pulmonary inflammation and asthma symptoms. A study in female adults discovered IL-6 was significantly higher in obese asthmatics compared to non-obese asthmatics and healthy controls ${ }^{47}$. This is yet to be confirmed in the paediatric population.

\section{Tumour Necrosis Factor-alpha (TNF- $\alpha)$}

TNF- $\alpha$ receptors are located on ASM cells and human in vivo studies have demonstrated airway hyper-responsiveness to TNF- $\alpha$ stimulation $^{19}$. TNF- $\alpha$ levels are reported to be 5.6 times higher in the alveolar macrophages of infants with wheeze compared to infants without wheeze ${ }^{49}$. A study conducted in children and adults found elevated levels of TNF- $\alpha$ and TNF receptor -1 and -2 in participants with bronchial hyper-reactivity when compared to those without hyper-reactivity ${ }^{50}$. In addition, these TNF markers negatively correlated with $\mathrm{FEV}_{1}{ }^{50}$.

Significantly elevated TNF- $\alpha$ levels were recently documented in obese adults with asthma when compared to obese adults without asthma and non-obese adults with and without asthma ${ }^{47}$. Although a $12 \mathrm{yr}$ paediatric follow-up study conducted in overweight and healthy weight children with or without asthma found no difference in TNF- $\alpha$ levels between the four groups, this study was limited by the small sample of asthmatic children and the disproportionate sample size across the four groups ${ }^{45}$. More insight is needed into the role of TNF- $\alpha$ in paediatric obese asthma.

\section{Weight Loss in Obese Children \& Adolescents}


Interventions to address paediatric obesity to date have used varying protocols. However, key features include dietary modification, increasing the ratio of physical activity to sedentary behaviour, and parental support for behaviour change ${ }^{51}$. In a small proportion of severely obese adolescents, bariatric surgery has become a consideration. Although no RCT has been conducted using bariatric surgery in $\underline{\text { severely obese adolescents, available evidence suggests this approach may result in a }}$ weak to moderate reduction in $\mathrm{BMI}^{52}$.

Table 2 presents a summary of lifestyle induced weight loss interventions in otherwise healthy children and adolescents and the effect upon inflammatory markers. Both long term and short term studies have achieved a significant alteration in the systemic inflammatory profile of obese participants following weight loss or a change in body composition.

Although a one year dietary intervention significantly reduced energy intake in all participants, a reduction in BMI was only achieved in $43 \%$ of the obese group ${ }^{53}$. Weight loss was accompanied by a 15\% increase in adiponectin and $19 \%$ reduction in leptin $^{53}$. Similarly, substantial weight loss following a combined diet, activity and behavioural intervention produced a significant decrease in CRP levels but no effect upon TNF- $\alpha$ levels $^{30}$ while a 1yr RCT found no reduction in CRP following a reduction in BMI Z-score in overweight and obese children ${ }^{54}$. In a small 3mth randomised study a favourable change in body composition but not BMI was detected in the intervention group, which was associated with significant reductions of $30 \%$ and $25 \%$ in CRP and IL- $6^{28}$. The same intervention period also achieved a $34 \%$ increase in adiponectin levels following positive body composition changes in obese adolescents $^{23}$.

In contrast to these long term interventions, a diet and exercise combination in obese children has effectively reduced CRP levels after 6wks following weight and percentage body fat reduction ${ }^{55}$. Furthermore, significant reductions in BMI, fat mass, IL-6 and leptin concentrations was achieved after only 3wks following a diet and physical activity intervention ${ }^{31}$. Unfortunately, the majority of studies to date have inadequately detailed the dietary intervention and the subsequent impact on dietary intake; failed to employ power calculations to determine sample size; not included 
adequate follow-up of participants; and used varying weight / adiposity indices and criteria used to classify obesity ${ }^{51}$. Although limited by design, overall these studies do suggest that relative body fat loss in obese children and adolescents is associated with a reduction in systemic inflammation.

\section{Weight Loss in Asthma}

Few weight loss intervention studies have been conducted in persons with asthma. Of those conducted, study participants have been adults and most weight loss has been surgically-induced $^{56}$. To date there have been no intervention studies designed to investigate the impact of weight loss in children / adolescents with asthma.

Only one adequately designed RCT, conducted in adults, met the criteria for a Cochrane review on dietary induced weight loss interventions in the population with asthma $^{57}$. The ineligible studies did not impose a weight loss intervention, were nonrandomised or uncontrolled. The RCT that was included randomised obese asthmatic adults to a control group or a $14 \mathrm{wk}$ weight reduction program that involved an $8 \mathrm{wk}$ very low calorie diet (VLCD) ${ }^{58}$. Compared to the control group, there was a significant improvement in $\mathrm{FEV}_{1}, \mathrm{FVC}$, and reported dyspnea and rescue medication use in the intervention group following a mean $14.5 \%$ weight loss ${ }^{58}$. Use of a VLCD in an 8wk non-randomised uncontrolled study in asthmatic adults produced a significant improvement in $\mathrm{FEV}_{1}, \mathrm{FVC}$, morning and evening peak expiratory flow and dyspnoea score following a mean weight loss of $13.5 \mathrm{~kg}^{59}$. A more recent uncontrolled study used an alternate day calorie restriction and ad libitum diet in 9 obese asthmatic adults for $8 \mathrm{wks}$ and reported a significant improvement in postsalbutamol $\mathrm{FEV}_{1}$ following an mean $8 \%$ weight loss $^{60}$. Another non-randomised uncontrolled 6mth intervention conducted in 58 obese females used a calorie restricted diet, including a $6 \mathrm{wk}$ or $12 \mathrm{wk}$ period of liquid meal replacements, depending on the level of obesity ${ }^{61}$. Greater weight loss was associated with significantly greater improvements in lung function $\left(\mathrm{FEV}_{1}, \mathrm{FVC}, \mathrm{TLC}\right)^{61}$.

Despite the limitations of small sample sizes, low power, predominant use of subjective reporting on asthma presence and status, and an inability of the study 
design to adequately control for potential confounders, previous studies have identified an improvement in some aspect of asthma following weight reduction in adults ${ }^{56}$ (See Figure 2). This is yet to be investigated in children and adolescents.

\section{Conclusion}

Obese asthma has emerged as a distinct clinical asthma phenotype in adults that may require a different treatment approach. Paediatric obese asthma may also emerge as a distinct phenotype, requiring a specialised treatment plan. As the number of children and adolescents with obese asthma increases, improvement in their management has the potential to greatly impact on population health. Although associations demonstrating a link between asthma and obesity in children and adolescents have been documented, there have been no weight loss intervention studies specifically conducted in children and adolescents with asthma, nor has the potential inflammatory link between the two chronic conditions been adequately explored. The few studies conducted in adults cannot be extrapolated to the paediatric population as the pathogenesis of asthma in children and adolescents follows a different pattern to that which occurs in adults. In order to optimise treatment strategies for obese children and adolescents with asthma, it is necessary to understand the nature of the existing airway inflammation. If a causal association between asthma and obesity in children and adolescents exists, then weight loss should reverse the negative impact of obesity on asthma status. High quality randomised controlled weight loss trials conducted in obese children and adolescents which assess airway inflammation and clinical asthma measures as primary outcomes are needed, in order to design optimal management approaches for these patients.

\section{Acknowledgements}

This work was supported by a Hunter Medical Research Institute project grant sponsored by the Gastronomic Society Lunch. 


\section{References}

[1] Masoli M, Fabian D, Holt S, Beasley R. Global Burden of Asthma: Global Initiative for Asthma; 2004.

[2] Australian Centre for Asthma Monitoring. Asthma in Australia 2008. Canberra: Australian Institute of Health and Welfare; 2008.

[3] World Health Organisation. Obesity and overweight. Global Strategy on Diet, Physical Activity and Health 2003 [cited 14/07/2009]; Available from: http://www.who.int/dietphysicalactivity/publications/facts/obesity/en/print.html

[4] Commonwealth Scientific Industrial Research Organisation (CSIRO) Preventative Health National Research Flagship, The University of South Australia. 2007 Australian National Children’s Nutrition and Physical Activity Survey Main Findings; 2008.

[5] Luder E, Melnik TA, DiMaio M. Association of being overweight with greater asthma symptoms in inner city black and Hispanic children. J Pediatr. April 1998;132(4):699-703.

[6] van Gent R, van der Ent C, Rovers M, Kimpen J, van Essen-Zandvliet L, de Meer G. Excessive body weight is associated with additional loss of quality of life in children with asthma J Allergy Clin Immunol. 2007;119:591-6.

[7] Gold D, Damokosh A, Dockery D, Berkey C. Body-Mass Index as a Predictor of Incident Asthma in a Prospective Cohort of Children. Pediatr Pulmonol. 2003;36:514-21.

[8] Gilliland F, Berhane K, Islam T, McConnell R, Gauderman WJ, Gilliland S, et al. Obesity and the Risk of Newly Diagnosed Asthma in School-age Children. Am J Epidemiol. 2003;158(5):406-15.

[9] Castro-Rodriguez JA, Holberg CJ, Morgan WJ, Wright AL, Martinez FD. Increased Incidence of Asthmalike Symptoms in Girls Who Become Overweight or Obese During the School Years. Am J Respir Crit Care Med. 2001;163:1344-9.

[10] Australian Centre for Asthma Monitoring. Asthma in Australian children: findings from Growing Up in Australia, the Longitudinal Study of Australian Children. Canberra; 2009. 
[11] Appleton SL, Adams RJ, Wilson DH, Taylor AW, Ruffin RE. Central obesity is associated with nonatopic but not atopic asthma in a representative population sample. Journal of Allergy and Clinical Immunology. 2006;118(6):1284-91.

[12] von Mutius E, Schwartz J, Neas LM, Dockery D, Weiss ST. Relation of body mass index to asthma and atopy in children: the National Health and Nutrition Examination Study III. Thorax. 2001;56:835-8.

[13] Jarvis D, Chinn S, Potts J, Burney P. Association of body mass index with respiratory symptoms and atopy: results from the European Community Respiratory Health Survey. Clin Exp Allergy. 2002 Jun;32(6):831-7.

[14] Haldar P, Pavord ID, Shaw DE, Berry MA, Thomas M, Brightling CE, et al. Cluster analysis and clinical asthma phenotypes. Am J Respir Crit Care Med. 2008 Aug 1;178(3):218-24.

[15] Pavord ID, Brightling CE, Woltmann G, Wardlaw AJ. Non-eosinophilic corticosteroid unresponsive asthma. Lancet. 1999;353:2213-14.

[16] Peters-Golden M, Swern A, Bird SS, Hustad CM, Grant E, Edelman JM. Influence of body mass index on the response to asthma controller agents. Eur Respir J. 2006;27:495-503.

[17] Kershaw E, Flier J. Adipose Tissue as an Endocrine Organ. J Clin Endocrinol Metab. 2004;89(6):2548-56.

[18] Fantuzzi G. Adipose tissue, adipokines, and inflammation. J Allergy Clin Immunol. 2005;115:911-9.

[19] Shore S, Johnston R. Obesity and Asthma. Pharmacol Ther. 2006;110:83-102.

[20] Auygun A, Gungor S, Ustundag B, Gurgoze M, Sen Y. Proinflammatory Cytokines and Leptin Are Increased in Serum of Prepubertal Obese Children. Mediators Inflamm. 2005;3:180-3.

[21] Ustundag B, Gungor S, Aygun A, Turgut M, Yilmaz E. Oxidative status and serum leptin levels in obese prepubertal children. Cell Biochem Funct. 2007;25:47983.

[22] Valle M, Martos R, Gascón F, Cañete R, Zafra M, Morales R. Low-grade systemic inflammation, hypoadiponectinemia and a high concentration of leptin are present in very young obese children, and correlate with metabolic syndrome. Diabetes Metab. 2005;31(1):55-62.

[23] Balagopal P, George D, Yarandi H, Funanage V, Bayne E. Reversal of Obesity-Related Hypoadiponectinemia by Lifestyle Intervention: A Controlled, 
Randomized Study in Obese Adolescents J Clin Endocrinol Metab. 2005;90(11):6192-7.

[24] Shin JY, Kim SY, Jeung MJ, Eun SH, Woo CW, Yoon S-Y, et al. Serum Adiponectin, C-Reactive Protein and TNF-alpha levels in Obese Korean Children. J Pediatr Endocrinol Metab. 2008;21:23-9.

[25] Kim KW, Shin YH, Lee KE, Kim ES, Sohn MH, Kim K-E. Relationship between adipokines and manifestations of childhood asthma. Pediatric Allergy \& Immunology. 2008 Sep;19(6):535-40.

[26] Retnakaren R, Hanley A, Connelly P, Harris S, Zinman B. Elevated CReactive protein in Native Canadian children: an ominous early complication of childhood obesity. Diabetes Obes Metab. 2006;8:483-91.

[27] Schwarzenberg S, Sinaiko A. Obesity and inflammation in children. Paediatr Respir Rev. 2006;7(4):239-46.

[28] Balagopal P, George D, Patton N, Yarandi H, Roberts M, Bayne E, et al. Lifestyle-only Intervention Attenuates the Inflammatory State Associated with Obesity: A Controlled Randomised Study in Adolescents. J Pediatr. 2005;146:342-8.

[29] Brasil A, Norton R, Rossetti M, Leão E, Mendes R. C-reactive protein as an indicator of low intensity inflammation in children and adolescents with and without obesity. Jornal de Pediatria. 2007;83(5):477-80.

[30] Reinher T, Stoffel-Wagner B, Roth C, Andler W. High-sensitive C-reactive protein, tumour necrosis factor $\alpha$, and cardiovascular risk factors before and after weight loss in obese children. Metabolism. 2005;54:1155-61.

[31] Gallistatl S, Sudi K, Aigner R, Borkenstein M. Changes in serum interleukin-6 concentrations in obese children and adolescents during a weight reduction program. Int J Obes. 2001;25:1640-3.

[32] Maffeis C, Silvagni D, Bonadonna R, Grezzani A, Banzato C, Tato L. Fat cell size, insulin sensitivity, and inflammation in obese children. J Pediatr. 2007;151(6):647-52.

[33] Velloso LA, Araujo EP, de Souza CT. Diet-induced inflammation of the hypothalamus in obesity. Neuroimmunomodulation. 2008;15(3):189-93.

[34] Lovett C, Whitehead B, Gibson P. Eosinophilic airway inflammation and the prognosis of childhood asthma. Clin Exp Allergy. 2007;37:1594-601.

[35] Wood L, Scott H, Garg M, Gibson P. Innate immune mechanisms linking nonesterified fatty acids and respiratory disease. Prog Lipid Res. 2008. 
[36] Gibson P, Simpson J, Saltos N. Heterogeneity of airway inflammation in persistent asthma. Chest. 2001;119:1329-36.

[37] Huang F, del R, o-Navarro BE, Sienra Monge JJ, Luis, Torres A, et al. Endothelial activation and systemic inflammation in obese asthmatic children. Allergy and Asthma Proceedings. 2008;29:453-60.

[38] Guler N, Kirerleri E, Ones U, Tamay Z, Salmayenli N, Darendeliler F. Leptin: does it have any role in childhood asthma? Journal of Allergy \& Clinical Immunology. 2004 Aug;114(2):254-9.

[39] Gurkan F, Atamar Y, Ece A, Kocyigit Y, Tuzun H, Mete N. Serum leptin levels in asthmatic children treated with an inhaled corticosteroid. Ann Allergy Asthma Immunol. 2004;93:277-80.

[40] Shin JH, Kim JH, Lee WY, Shim JY. The expression of adiponectin receptors and the effects of adiponectin and leptin on airway smooth muscle cells. Yonsei Med J. 2008 Oct 31;49(5):804-10.

[41] Shore SA, Schwartzman IN, Mellema MS, Flynt L, Imrich A, Johnston RA. Effect of leptin on allergic airway responses in mice. J Allergy Clin Immunol. 2005 Jan;115(1):103-9.

[42] Shore SA, Rivera-Sanchez YM, Schwartzman IN, Johnston RA. Responses to ozone are increased in obese mice. J Appl Physiol. 2003 Sep;95(3):938-45.

[43] Mancuso P, Huffnagle GB, Olszewski MA, Phipps J, Peters-Golden M. Leptin corrects host defense defects after acute starvation in murine pneumococcal pneumonia. Am J Respir Crit Care Med. 2006 Jan 15;173(2):212-8.

[44] Jartti T, Saarikoski L, Jartti L, Lisinen I, Jula A, Huupponen R, et al. Obesity, adipokines and asthma. Allergy. 2009 May

May;64(5):770-7.

[45] Mai X-M, Bo“ ttcher M, Leijon I. Leptin and asthma in overweight children at 12 years of age. Pediatr Allergy Immunol. 2004;15(6):523-30.

[46] Soferman R, Glatstein M, Sivan Y, Weisman Y. HsCRP levels: Measurement of airway infl ammation in asthmatic children. Pediatr Int. 2008;50:12-6.

[47] Canoz M, Erdenen F, Uzun H, Muderrisoglu C, Aydin S. The relationship of inflammatory cytokines with asthma and obesity. Clinical \& Investigative Medicine. 2008 12;31(6):E373-E9.

[48] Kicic A, Sutanto EN, Stevens PT, Knight DA, Stick SM. Intrinsic biochemical and functional differences in bronchial epithelial cells of children with asthma. 
American Journal of Respiratory \& Critical Care Medicine. 2006 Nov;174(10):11108.

[49] Chedevergne F, Le Bourgeois M, de Blic J, Scheinmann P. The role of inflammation in childhood asthma. Arch Dis Child. 2000;82(Supp 2):ii6-ii9.

[50] Halasz A, Cserhati E, Magyar P, KovÁCs M, Cseh K. Role of TNF- [alpha] and its 55 and $75 \mathrm{kDa}$ receptors in bronchial hyperreactivity. Respir Med. 2002;96(4):262-7.

[51] Collins C, Warren J, Neve M, McCoy P, Stokes B. Measuring Effectiveness of Dietary Interventions in Child Obesity: A Systematic Review of Randomised Trials. Arch Pediatr Adolesc Med. 2006;160:906-22.

[52] Baur LA, Fitzgerald DA, Armstrong GT, Bailey D, Batch J, Dixon J, et al. Recommendations for Bariatric Surgery in Adolescents in Australia and New Zealand: A paper from the Australian and New Zealand Association of Paediatric Surgeons, the Obesity Surgery Society of Australia and New Zealand and the Paediatric \& Child Health Division of The Royal Australasian College of Physicians; March 2010.

[53] Reinher T, Roth C, Alexy U, Kersting M, Kiess W, Andler W. Ghrelin levels before and after reduction of overweight due to a low-fat high-carbohydrate diet in obese children and adolescents. Int J Obes. 2005;29:362-8.

[54] Okely AD, Collins CE, Morgan PJ, Jones RA, Warren JM, Cliff DP, et al. Multi-site randomized controlled trial of a child-centred physical activity program, a parent-centred dietary-modification program, or both in obese children: The HIKCUPS study. The Journal of Paediatrics. 19th March 2010;In press.

[55] Kelishadi R, Hashemi M, Mohammadifard N, Asgary S, Khavarian N. Association of Changes in Oxidative and Proinflammatory States with Changes in Vascular Function after a Lifestyle Modification Trial Among Obese Children. Clin Chem. 2008;54(1):147-53.

[56] Eneli IU, Skybo T, Camargo CA, Jr. Weight loss and asthma: a systematic review. Thorax. 2008 Aug;63(8):671-6.

[57] Cheng J, Pan T. Calorie controlled diet for chronic asthma. Cochrane Database Syst Rev. 2003(2).

[58] Stenius-Aarniala B, Poussa T, Kvarnstrom J, Gronlund EL, Ylikahri M, Mustajoki P. Immediate and long term effects of weight reduction in obese people with asthma: randomised controlled study. BMJ. 2000 Mar 25;320(7238):827-32. 
[59] Hakala K, Stenius-Aarniala B, Sovijarvi A. Effects of weight loss on peak flow variability, airways obstruction, and lung volumes in obese patients with asthma. Chest. 2000 Nov;118(5):1315-21.

[60] Johnson JB, Summer W, Cutler RG, Martin B, Hyun D-H, Dixit VD, et al. Alternate day calorie restriction improves clinical findings and reduces markers of oxidative stress and inflammation in overweight adults with moderate asthma. Free Radic Biol Med. 2007 Mar 1;42(5):665-74.

[61] Aaron SD, Fergusson D, Dent R, Chen Y, Vandemheen KL, Dales RE. Effect of weight reduction on respiratory function and airway reactivity in obese women. Chest. 2004 Jun;125(6):2046-52.

[62] Visser M, Bouter LM, McQuillan GM, Wener MH, Harris TB. Low-Grade Systemic Inflammation in Overweight Children. Paediatr. 2001;107(1):E13.

[63] Reinher T, Roth C, Menke T, Andler W. Adiponectin before and after Weight Loss in Obese Children. J Clin Endocrinol Metab. 2004;89:3790-4. 


\section{Tables}

Table 1: Cross-sectional studies in children and adolescents that have measured markers of inflammation

\begin{tabular}{|c|c|c|c|c|c|c|}
\hline $\begin{array}{l}\text { Inflammatory } \\
\text { Marker }\end{array}$ & Study Design & Population & Groups & Obesity definition & $\mathbf{n}$ & Inflammatory Difference \\
\hline \multirow{6}{*}{ Leptin } & Cross-sectional $^{21}$ & $7-10 y$ & O vs NO & $\begin{array}{l}\text { BMI SDS >3 (Turkish reference } \\
\text { population) }\end{array}$ & $0=60, \mathrm{NO}=60$ & $\uparrow$ leptin in O vs NO. \\
\hline & Cross-sectional ${ }^{25}$ & mean 9.8y & AA vs NAA vs HC & $\begin{array}{l}\text { age and sex specific BMI percentiles } \\
\text { based on international data that } \\
\text { correspond to adult BMI values of } 25 \text { and } \\
30 \mathrm{~kg} / \mathrm{m} 2 \text { (Cole et al, 2000) }\end{array}$ & $\begin{array}{l}\mathrm{AA}=149 ; \\
\mathrm{NAA}=37 \\
\mathrm{HC}=54 \text { (of } \\
\text { which } \mathrm{HW}=158 ; \\
\mathrm{OW}=43 ; \mathrm{O}=39 \text { ) }\end{array}$ & $\begin{array}{l}\text { Leptin was not significantly different between } \\
\text { AA, NAA and HC. Leptin differed significantly } \\
\text { between HW, OW and O groups (values by } \\
\text { weight status not provided). Leptin positively } \\
\text { correlated with BMI percentile. }\end{array}$ \\
\hline & $\begin{array}{l}\text { Cross-sectional + } \\
\text { pharmacological } \\
\text { intervention }\end{array}$ & $\begin{array}{l}\text { HWA: mean } \\
6.4 y ; \text { HW } \\
\text { controls: mean } \\
7 y\end{array}$ & $\begin{array}{l}\text { HWA vs HW } \\
\text { controls }\end{array}$ & $\begin{array}{l}\text { HWA: mean BMI } 16.7 \mathrm{~kg} / \mathrm{m} 2 ; \mathrm{HW} \text { : mean } \\
\text { BMI } 16.9 \mathrm{~kg} / \mathrm{m} 2\end{array}$ & $\begin{array}{l}\mathrm{HWA}=23 \\
\mathrm{HW}=20\end{array}$ & $\uparrow$ leptin in HWA vs HW controls \\
\hline & Cross-sectional $^{38}$ & $\begin{array}{l}\text { HWA mean } \\
5.9 y ; \text { HW } \\
\text { controls mean } \\
6.1 y\end{array}$ & $\begin{array}{l}\text { HWA vs HW } \\
\text { controls }\end{array}$ & BMI used. No groupings. & $\begin{array}{l}\text { HWA=102 } \\
\text { (65M:37F); HW } \\
\text { controls=33 } \\
(19 \mathrm{M}: 14 \mathrm{~F}) \\
\end{array}$ & $\uparrow$ leptin in HWA vs HW controls in males \\
\hline & Case-control $^{22}$ & $6-9 y$ & O vs NO & $\begin{array}{l}>90 \text { th BMI percentile for reference } \\
\text { population }\end{array}$ & $\mathrm{O}=51 ; \mathrm{NO}=51$ & $\begin{array}{l}\uparrow \text { leptin in O vs NO. Leptin an independent } \\
\text { predictor of BMI in O. }\end{array}$ \\
\hline & Case-control $^{20}$ & $7-10 y$ & O vs NO & $\begin{array}{l}120 \% \text { mean BW for Turkish reference } \\
\text { population and when BMI for age }>99 \text { th } \%\end{array}$ & $\mathrm{O}=63 ; \mathrm{NO}=63$ & $\begin{array}{l}\uparrow \text { leptin in O vs NO. Leptin correlated with } \\
\text { BMI in obese. }\end{array}$ \\
\hline \multirow{3}{*}{ Adiponectin } & Case-control $^{22}$ & $6-9 y$ & O vs NO & $\begin{array}{l}\text { >90th BMI percentile for reference } \\
\text { population }\end{array}$ & $\mathrm{O}=51 ; \mathrm{NO}=51$ & $\begin{array}{l}\downarrow \text { adiponectin in O vs NO. Adiponectin } \\
\text { correlated negatively with BMI. }\end{array}$ \\
\hline & Cross-sectional $^{25}$ & mean 9.8y & AA vs NAA vs $H C$ & $\begin{array}{l}\text { age and sex specific BMI percentiles } \\
\text { based on international data that } \\
\text { correspond to adult BMl values of } 25 \text { and } \\
30 \mathrm{~kg} / \mathrm{m} 2 \text { (Cole et al, 2000) }\end{array}$ & $\begin{array}{l}\mathrm{AA}=149 ; \\
\mathrm{NAA}=37 \\
\mathrm{HC}=54 \text { (of } \\
\text { which } \mathrm{HW}=158 ; \\
\mathrm{OW}=43 ; \mathrm{O}=39 \text { ) }\end{array}$ & $\begin{array}{l}\text { Adiponectin was not significantly different } \\
\text { between AA, NAA and HC. Adiponectin } \\
\text { differed significantly between HW, OW and O } \\
\text { groups (values by weight status not } \\
\text { provided). Adiponectin negatively correlated } \\
\text { with BMI percentile. }\end{array}$ \\
\hline & Case-control $^{24}$ & $8-15 y$ & O vs NO & $\begin{array}{l}\geq 95 \text { th percentile } \&<85 \text { th percentile } \\
\text { (reference population not specified) }\end{array}$ & $\mathrm{O}=73 ; \mathrm{NO}=30$ & $\begin{array}{l}\downarrow \text { adiponectin in O vs NO. Adiponecitn } \\
\text { negatively correlated with BMI }\end{array}$ \\
\hline
\end{tabular}




\begin{tabular}{|c|c|c|c|c|c|c|}
\hline & Cross-sectional $^{23}$ & $14-18 y$ & HW vs O & $\mathrm{BMI}>30$ & $\mathrm{HW}=6 ; \mathrm{O}=15$ & $\begin{array}{l}\downarrow \text { adiponectin levels in O vs HW. BMI, BF\% \& } \\
\text { trunk fat mass negatively correlated with } \\
\text { adiponectin levels. LM\% positively associated } \\
\text { with adiponectin. }\end{array}$ \\
\hline \multirow{7}{*}{ CRP } & Cross-sectional ${ }^{29}$ & 2.3-19y & O vs NO & $\begin{array}{l}\text { BMI percentiles (NCHS } 2000 \text { reference } \\
\text { values). Obese: >95th percentile }\end{array}$ & $\begin{array}{l}\mathrm{O}=131 \\
\mathrm{NO}=114\end{array}$ & $\begin{array}{l}\uparrow \text { hsCRP in O vs NO. Relationship between } \\
\text { hsCRP and BMI. }\end{array}$ \\
\hline & Cross-sectional ${ }^{62}$ & $8-16 y$ & $\begin{array}{l}\text { representative } \\
\text { sample of US } \\
\text { children (NHANES } \\
\text { III) }\end{array}$ & $\begin{array}{l}>85 \text { th BMI percentile or sum of } 3 \text { skinfolds } \\
\text { for reference population (NHANES III) }\end{array}$ & $n=3512$ & $\begin{array}{l}\text { OW more likely to have } \uparrow \text { CRP (OR } 3.17 \text { girls } \\
\text { and } 3.74 \text { boys based on BMI or } 5.11 \text { boys } \\
\text { and } 2.89 \text { girls based on skinfolds) }\end{array}$ \\
\hline & Cross-sectional ${ }^{37}$ & $10-16 y$ & $\begin{array}{l}\text { O vs NO vs NOA } \\
\text { vs OA }\end{array}$ & $\begin{array}{l}\text { CDC BMI percentiles. Obese: >95th } \\
\text { percentile; Healthy weight: <85th } \\
\text { percentile }\end{array}$ & $\begin{array}{l}\mathrm{OA}=33 \\
\mathrm{NOA}=19 ; \mathrm{O}=37 \\
\mathrm{NO}=20\end{array}$ & No difference \\
\hline & Cross-sectional ${ }^{28}$ & $15-16 y$ & $\mathrm{HW}$ vs O & $\mathrm{BMI}>30$ & $\mathrm{HW}=6 ; \mathrm{O}=15$ & $\begin{array}{l}\uparrow \mathrm{CRP} \text { in O vs HW. CRP positively correlated } \\
\text { with BMI \& BF\%. }\end{array}$ \\
\hline & Cross-sectional ${ }^{30}$ & Mean age $11 y$ & O vs NO & $\begin{array}{l}\text { 297th BMI percentile based on population- } \\
\text { specific data }\end{array}$ & $\mathrm{NO}=14 ; \mathrm{O}=31$ & $\begin{array}{l}\uparrow \text { hsCRP in O vs NO. hsCRP correlated with } \\
\text { SDS-BMI. }\end{array}$ \\
\hline & Case-control $^{22}$ & $6-9 y$ & O vs NO & $\begin{array}{l}\text { >90th BMI percentile for reference } \\
\text { population }\end{array}$ & $\mathrm{O}=51 ; \mathrm{NO}=51$ & $\begin{array}{l}\uparrow \mathrm{CRP} \text { in O vs NO. logCRP positively } \\
\text { correlated with BMI. }\end{array}$ \\
\hline & Case-control $^{24}$ & 8-15y & O vs NO & $\begin{array}{l}\geq 95 \text { th percentile } \&<85 \text { th percentile } \\
\text { (reference population not specified) }\end{array}$ & $\mathrm{O}=73 ; \mathrm{No}=30$ & $\begin{array}{l}\uparrow \mathrm{CRP} \text { in O vs NO. CRP positively correlated } \\
\text { with BMI. }\end{array}$ \\
\hline \multirow{4}{*}{ IL-6 } & Case-control $^{22}$ & $6-9 y$ & O vs NO & $\begin{array}{l}>90 \text { th BMI percentile for reference } \\
\text { population }\end{array}$ & $\mathrm{O}=51 ; \mathrm{NO}=51$ & ^ IL-6 in O vs NO. \\
\hline & Cross-sectional $^{28}$ & $15-16 y$ & HW vs O & $\mathrm{BMI}>30$ & $\mathrm{HW}=6 ; \mathrm{O}=15$ & $\begin{array}{l}\uparrow \text { IL-6 in O vs HW. IL-6 positively correlated } \\
\text { with BMI \& BF\%. }\end{array}$ \\
\hline & Cross-sectional ${ }^{31}$ & $10-13 y$ & HW vs O & $\begin{array}{l}\text { BMI>85th percentile for age and sex } \\
\text { (NHANES I data) }\end{array}$ & $\mathrm{O}=49 ; \mathrm{HW}=69$ & $\begin{array}{l}\uparrow \text { IL- } 6 \text { in O vs HW. No correlation between } \\
\text { IL- } 6 \text { and BMI/FM/\%FM. }\end{array}$ \\
\hline & Case-control $^{20}$ & $7-10 y$ & O vs NO & $\begin{array}{l}120 \% \text { mean BW for Turkish school } \\
\text { children national data and when BMI } \\
\text { >99th percentile in study population } \\
\text { growth curve }\end{array}$ & $\mathrm{O}=63 ; \mathrm{NO}=63$ & ^ IL-6 in O vs NO. \\
\hline \multirow{2}{*}{ TNF- $\alpha$} & Cross-sectional $^{30}$ & Mean age $11 y$ & O vs NO & $\begin{array}{l}\text { 97th BMI percentile based on population- } \\
\text { specific data }\end{array}$ & $\mathrm{NO}=14 ; \mathrm{O}=31$ & $\begin{array}{l}\uparrow \text { TNF- } \alpha \text { in O vs NO. TNFa correlated with } \\
\text { SDS-BMI. }\end{array}$ \\
\hline & Case-control ${ }^{24}$ & 8-15y & O vs NO & 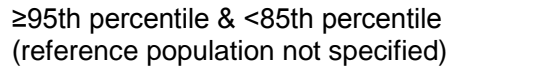 & $\mathrm{O}=73 ; \mathrm{No}=30$ & $\begin{array}{l}\uparrow \text { TNF- } \alpha \text { in O group vs NO. TNF positively } \\
\text { correlated with BMI. }\end{array}$ \\
\hline
\end{tabular}




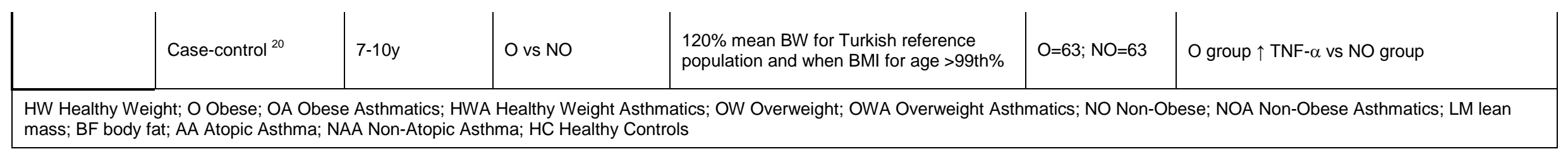


Table 2: Weight loss studies in children and adolescents that have measured markers of inflammation

\begin{tabular}{|c|c|c|c|c|c|c|c|c|}
\hline $\begin{array}{l}\text { Inflammatory } \\
\text { Marker }\end{array}$ & $\begin{array}{l}\text { Study } \\
\text { Design }\end{array}$ & Population & Obesity definition & Intervention & Length & $\mathbf{n}$ & Weight change & Inflammatory Difference \\
\hline \multirow[b]{2}{*}{ Leptin } & $\begin{array}{l}\text { Uncontrolled } \\
\text { longitudinal } \\
31\end{array}$ & $10-13 y$ & $\begin{array}{l}\text { BMI percentile }>85^{\text {th }} \\
\text { for age and sex } \\
\text { (NHANES I data) }\end{array}$ & $\begin{array}{l}\text { restricted energy } \\
\text { intake }(3.8-5 \mathrm{MJ})+ \\
\text { PA }\end{array}$ & $3 w k s$ & $\begin{array}{l}49 \\
(31 F: 18 M)\end{array}$ & $\downarrow \mathrm{BMI}, \mathrm{BF} \& \% \mathrm{BF}$ & $\downarrow$ leptin \\
\hline & $\begin{array}{l}\text { Uncontrolled } \\
\text { longitudinal } \\
\text { (subgroups } \\
\text { based on } \\
\text { LOW) }\end{array}$ & 8-13y & $\begin{array}{l}\geq 97 \text { th } \text { BMI percentile } \\
\text { based on German } \\
\text { population }\end{array}$ & Diet (HC, LF) & $1 \mathrm{yr}$ & 37 & $\begin{array}{l}\text { Group 1: } n=16 \text { obese LOW } \geq 0.5 \text { BMI- } \\
\text { SDS; Group 2: } n=21 \text { obese LOW } \\
<0.5 \text { BMI-SDS }\end{array}$ & $\begin{array}{l}\text { Group } 1: \downarrow \text { leptin. Group } 2 \text { : } \\
\text { no change }\end{array}$ \\
\hline \multirow{3}{*}{ Adiponectin } & $\mathrm{RCT}^{23}$ & $14-18 y$ & BMI >30 & $\begin{array}{l}\text { PA-behavioral-diet } \\
\text { intervention based } \\
\text { on 'Shapedown' }\end{array}$ & 3mths & $\begin{array}{l}\text { Control=7; } \\
\text { Intervention } \\
=8\end{array}$ & $\begin{array}{l}\text { Intervention group: no change in BW } \\
\text { / BMI ( } \downarrow \text { BF\% } \uparrow \mathrm{LM} \%) \text {. Control group } \\
\text { gained BW. }\end{array}$ & $\begin{array}{l}\text { Intervention: } \uparrow 34 \% \\
\text { adiponectin. Control: no } \\
\text { change }\end{array}$ \\
\hline & $\begin{array}{l}\text { Uncontrolled } \\
\text { longitudinal } \\
63\end{array}$ & $\begin{array}{l}\text { Mean age } \\
10.2 y\end{array}$ & $\begin{array}{l}\geq 97 \text { th BMI percentile } \\
\text { based on population- } \\
\text { specific data }\end{array}$ & $\begin{array}{l}\text { Based on } \\
\text { 'Obeldicks' program } \\
\text { (HC, LF diet, PA, } \\
\text { behaviour) }\end{array}$ & $1 \mathrm{yr}$ & $\begin{array}{l}42 \\
(24 \mathrm{~F}: 18 \mathrm{M})\end{array}$ & $\begin{array}{l}\text { Group I: } \mathrm{n}=16 \text { obese with LOW } \geq 0.5 \\
\text { BMI-SDS; Group 2: } \mathrm{n}=26 \text { obese with } \\
\text { LOW <0.5 BMI-SDS. However, no } \\
\text { significant difference in BMI-SDS or } \\
\text { BF\% between Group I \& II. }\end{array}$ & $\begin{array}{l}\text { Group I: } \downarrow \text { adiponectin } \\
\text { levels. Group II: no } \\
\text { difference }\end{array}$ \\
\hline & $\begin{array}{l}\text { Uncontrolled } \\
\text { longitudinal }\end{array}$ & $8-13 y$ & $\begin{array}{l}\geq 97 \text { th } \text { BMI percentile } \\
\text { based on German } \\
\text { population }\end{array}$ & Diet (HC, LF) & $1 \mathrm{yr}$ & 37 & $\begin{array}{l}\text { Group 1: } n=16 \text { obese with LOW } \geq 0.5 \\
\text { BMI-SDS; Group } 2: n=21 \text { obese } \\
\text { children with LOW }<0.5 \text { BMI-SDS }\end{array}$ & $\begin{array}{l}\text { Group 1: } \uparrow \text { adiponectin. } \\
\text { Group 2: no effect. }\end{array}$ \\
\hline \multirow{3}{*}{ CRP } & $\mathrm{RCT}^{28}$ & $15-16 y$ & $\mathrm{BMI}>30$ & $\begin{array}{l}\text { PA-behavioral-diet } \\
\text { intervention based } \\
\text { on 'Shapedown' }\end{array}$ & 3mths & $\begin{array}{l}\text { Control=7; } \\
\text { Intervention } \\
=8\end{array}$ & $\begin{array}{l}\text { Intervention group maintained BW } \\
(\uparrow F F M \%, \downarrow B F \%) \text {. Control group } \\
\text { gained BW }\end{array}$ & $\begin{array}{l}\text { Intervention group: } \downarrow \text { CRP. } \\
\text { Control group: no change. }\end{array}$ \\
\hline & $\mathrm{RCT}^{23}$ & $14-18 y$ & $\mathrm{BMI}>30$ & $\begin{array}{l}\text { PA-behavioral-diet } \\
\text { intervention based } \\
\text { on 'Shapedown' }\end{array}$ & 3mths & $\begin{array}{l}\text { Control=7; } \\
\text { Intervention } \\
=8\end{array}$ & $\begin{array}{l}\text { Intervention group: no change in BW } \\
\text { / BMI ( } \downarrow \text { BF\% } \uparrow \mathrm{LM} \%) \text {. Control group } \\
\text { gained weight. }\end{array}$ & $\begin{array}{l}\text { Intervention: } \downarrow \text { CRP. } \\
\text { Control: no change }\end{array}$ \\
\hline & $\begin{array}{l}\text { Randomised } \\
\text { uncontrolled } \\
55\end{array}$ & 12-18y & $\begin{array}{l}\text { Obesity: BMI } \\
\text { percentile } \geq 95 \text { th (CDC) }\end{array}$ & Diet + PA & $6 w k s$ & $\begin{array}{l}35 \\
(19 \mathrm{M}: 16 \mathrm{~F})\end{array}$ & $\downarrow$ BMI, BMI-SDS, BF\%, WC \& BW & $\downarrow \mathrm{CRP}$ \\
\hline
\end{tabular}




\begin{tabular}{|c|c|c|c|c|c|c|c|c|}
\hline & $\begin{array}{l}\text { Uncontrolled } \\
\text { longitudinal } \\
30\end{array}$ & $\begin{array}{l}\text { Mean age } \\
11 y\end{array}$ & $\begin{array}{l}\geq 97 \text { th BMI percentile } \\
\text { based on population- } \\
\text { specific data }\end{array}$ & $\begin{array}{l}\text { Diet based on } \\
\text { 'Obeldicks' program } \\
\text { (HC, LF diet, PA, } \\
\text { behaviour) }\end{array}$ & $1 \mathrm{yr}$ & 31 & $\begin{array}{l}\text { Group 1: } n=16 \text { obese with LOW } \geq 0.5 \\
\text { BMI-SDS (median reduction of } \\
0.66 \text { BMI-SDS); Group } 2: n=15 \text { obese } \\
\text { children with LOW }<0.05 \text { BMI-SDS } \\
\text { (median reduction of } 0.1 \text { BMI-SDS). }\end{array}$ & $\begin{array}{l}\text { Group 1: } \downarrow \text { hsCRP. Group } \\
\text { 2: no change. }\end{array}$ \\
\hline & $\mathrm{RCT}^{54}$ & $5.5-9.99 y$ & $\begin{array}{l}\text { Overweight and } \\
\text { obese: defined } \\
\text { according to the } \\
\text { International Obesity } \\
\text { Task Force cut-off } \\
\text { points }\end{array}$ & $\begin{array}{l}3 \text { treatment groups: } \\
\text { Diet OR PA OR } \\
\text { Diet + PA }\end{array}$ & $1 \mathrm{yr}$ & $\begin{array}{l}\text { Diet=42; } \\
\text { PA=63; } \\
\text { Diet+PA=60 }\end{array}$ & $\begin{array}{l}\text { All groups had a reduction in BMI z- } \\
\text { score. However, greater reductions } \\
\text { were seen in Diet group and Diet + } \\
\text { PA group. }\end{array}$ & $\begin{array}{l}\text { No difference in CRP } \\
\text { within or between groups. }\end{array}$ \\
\hline \multirow{3}{*}{ IL-6 } & $\mathrm{RCT}^{28}$ & $15-16 y$ & $\mathrm{BMI}>30$ & $\begin{array}{l}\text { PA-behavioral-diet } \\
\text { intervention based } \\
\text { on 'Shapedown' }\end{array}$ & 3 mths & $\begin{array}{l}\text { Control=7; } \\
\text { Intervention } \\
=8\end{array}$ & $\begin{array}{l}\text { Intervention group maintained BW } \\
\text { ( } \uparrow L M \%, \downarrow B F \%) \text {. Control group gained } \\
\text { BW }\end{array}$ & $\begin{array}{l}\text { Intervention group: } \downarrow \text { IL-6. } \\
\text { Control group: no change. }\end{array}$ \\
\hline & $\mathrm{RCT}^{23}$ & $14-18 y$ & $\mathrm{BMI}>30$ & $\begin{array}{l}\text { PA-behavioral-diet } \\
\text { intervention based } \\
\text { on 'Shapedown' }\end{array}$ & 3mths & $\begin{array}{l}\text { Control=7; } \\
\text { Intervention } \\
=8\end{array}$ & $\begin{array}{l}\text { Intervention group: no change in BW } \\
\text { / BMI }(\downarrow \mathrm{BF} \% \uparrow \mathrm{LM} \%) \text {. Control group } \\
\text { gained weight. }\end{array}$ & $\begin{array}{l}\text { Intervention: } \downarrow \text { IL-6. } \\
\text { Control: no change }\end{array}$ \\
\hline & $\begin{array}{l}\text { Uncontrolled } \\
\text { longitudinal } \\
31\end{array}$ & $10-13 y$ & $\begin{array}{l}\text { BMI percentile >85th } \\
\text { for age and sex } \\
\text { (NHANES I data) }\end{array}$ & $\begin{array}{l}\text { energy intake } \\
\text { restriction to } 3.8 \text { - } \\
5 \mathrm{MJ}+\mathrm{PA}\end{array}$ & $3 w k s$ & $\begin{array}{l}49 \\
(31 \mathrm{~F}: 18 \mathrm{M})\end{array}$ & $\downarrow \mathrm{BMI}, \mathrm{BF} \& \% \mathrm{BF}$ & $\downarrow$ IL-6 \\
\hline TNF- $\alpha$ & $\begin{array}{l}\text { Uncontrolled } \\
\text { longitudinal } \\
\text { (subgroups } \\
\text { based on } \\
\text { LOW) }{ }^{30}\end{array}$ & $\begin{array}{l}\text { Mean age } \\
11 y\end{array}$ & $\begin{array}{l}\geq 97 \text { th BMI percentile } \\
\text { based on population- } \\
\text { specific data }\end{array}$ & $\begin{array}{l}\text { Diet based on } \\
\text { 'Obeldicks' program } \\
\text { (HC, LF diet, PA, } \\
\text { behaviour) }\end{array}$ & $1 \mathrm{yr}$ & 31 & $\begin{array}{l}\text { Group 1: } n=16 \text { obese with LOW } \geq 0.5 \\
\text { BMI-SDS (median reduction of } \\
0.66 \text { SDS-BMI); Group } 2: \mathrm{n}=15 \text { obese } \\
\text { children with LOW }<0.05 \text { BMI-SDS } \\
\text { (median reduction of } 0.1 \text { BMI-SDS). }\end{array}$ & $\begin{array}{l}\text { Group } 1 \text { \& Group 2: no } \\
\text { change. }\end{array}$ \\
\hline
\end{tabular}




\section{Figure Legends}

\section{Figure 1.}

Excess adiposity increases systemic inflammation, subsequently augmenting airway inflammation and contributing to asthma pathogenesis. AHR airway hyperresponsiveness; ASM airway smooth muscle.

\section{Figure 2.}

Improvements in asthma measures following weight loss in adults with asthma. ASM airway smooth muscle. 


\section{Figures}

Figure 1

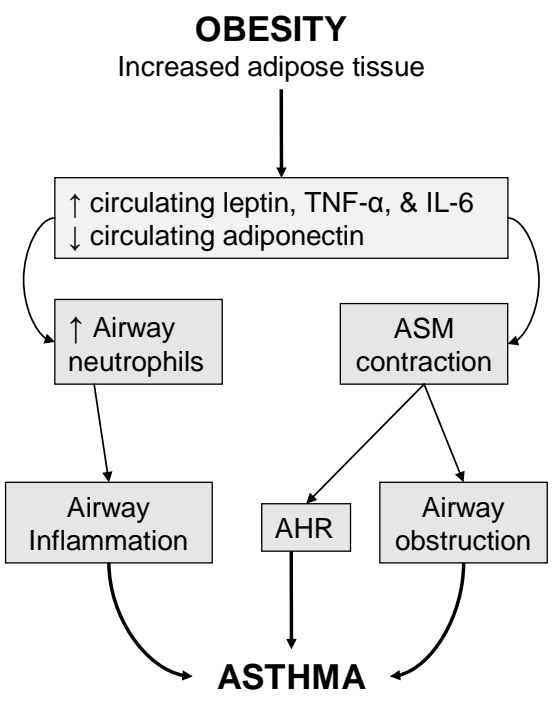


Figure 2

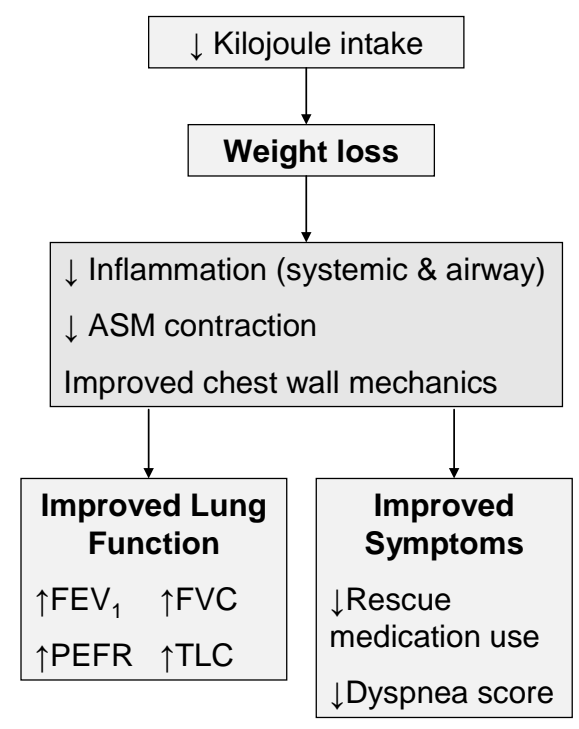

